\title{
ADVENTURE TOURISM IN SUTJESKA NATIONAL PARK
}

\author{
Edin Hrelja ${ }^{1}$ \\ Nusret Drešković ${ }^{2}$ \\ Ranko Mirić ${ }^{3}$ \\ Amra Čaušević ${ }^{4}$
}

\begin{abstract}
The subject of the research is Sutjeska National Park, with special attention on the possibilities of establishing and developing adventure tourism. Sutjeska National Park is one of the four national parks in Bosnia and Herzegovina. It was founded in 1962, which makes it the oldest National Park. It was declared a protected area due to the famous Battle of Sutjeska during the Second World War, but also due to the existence of a significant natural geographical basis. A large number of cultural and historical monuments, Perućica rainforest, Maglić and Zelengora mountains, the mountain lakes, Sutjeska, and Hrčavka rivers are just some of the tourist potentials of the protected natural area.

Until 1992, tourist activities in this area were based mainly on the achievements of the national struggle for liberation. After 1995, the interest of tourists in this type of tourism decreased to a large extent, so complementary tourist activities began to develop. To complete the tourist offer in Sutjeska national park, adventure tourism is being developed (hiking, mountaineering, alpine climbing, cycling, rafting, etc.). Given the natural geographical and cultural-historical elements, the Sutjeska national park is an ideal area for the development of this type of tourism, which contributes to the completion of the tourist offer.
\end{abstract}

Keywords: adventure tourism, tourism, Sutjeska, protected area, national park

\section{INTRODUCTION}

Tourism is one of the fastest-growing economic sectors today, with adventure tourism developing very rapidly. ATTA (Adventure Travel Trade Association) defines adventure tourism as a trip that includes the following elements: physical activity, natural environment and contact with the culture of the locality. Also, adventure tourism is defined as a form of nature tourism that includes an element of risk, a higher level of physical exhaustion, and the need for a specialized skill. From a global perspective, adventure tourism is considered as tourism that respects the natural and cultural values of the destination, is economically sustainable and socially just because it protects the most vulnerable groups (Dražina, A., 2017). In the last ten years, the motives of tourists who want to meet the needs of adventure tourism have changed. Earlier, the emphasis was on risk, and today on the natural environment, research and learning.

\footnotetext{
${ }^{1}$ Ph.D. in Geography, Assistant professor, Department of Geography, Faculty of Science, University of Sarajevo, Bosnia and Herzegovina. e-mail: edin_hrelja@yahoo.com.

${ }^{2}$ Ph.D. in Geography, Full professor, Department of Geography, Faculty of Science, University of Sarajevo, Bosnia and Herzegovina.

${ }^{3}$ Ph.D. in Geography, Associate professor, Department of Geography, Faculty of Science, University of Sarajevo, Bosnia and Herzegovina.

${ }^{4}$ Ph.D. in Geography, Assistant professor, Department of Geography, Faculty of Science, University of Sarajevo, Bosnia and Herzegovina
} 
Sutjeska National Park was declared a protected natural area in 1962. It was singled out in that category of protection primarily because of its memorial significance from the National Liberation War, but also because of its complementary natural geographical sights, which make up the rare contents and diversity of its natural heritage (geological, geomorphological and biological). The separation of the protected natural area has contributed to its tourist development. Tourism development was accompanied by an increase in the number of visitors, which in the pre-war period reached the number of 900,000 visits (PP NP Sutjeska, 2013). The events of the war, including the destruction of the material structure, affected the development of tourism in the Park significantly in the period from the mid-1990s (6,000 visits (PP NP Sutjeska, 2013), almost to the initial level from the early 1960s. Recently, especially after the adoption of the protection regime according to the IUCN classification in 2003, the situation is gradually improving. Devastated tourist facilities and accompanying infrastructure are being renovated, as a precondition for a new stage of tourist development (Hrelja, E., 2017). In order to increase the number of tourists who will not have adverse effects that are contrary to the protection regime, complementary forms of tourist movements are being developed. Due to the physical-geographical specifics of the area, the development of adventure tourism occupies a special place in such tourist development.

\section{METHODOLOGY OF THE RESEARCH}

The research methodology is defined according to the title of the paper and the set goals of the research. The subject of the research is adventure tourism in the Sutjeska National Park, where the peculiarities of tourist potentials are presented, based on which the types of adventure tourism are singled out. Scientific methods that were applied in the research are the method of spatial analysis, the method of interviews, the GIS method, and the method of field observations.

In the initial phase of the research, a spatial analysis of the possibilities for the development of adventure tourism was performed through the collection and insight into relevant literature related to the field of research-opportunities for the development of adventure tourism following the previously conducted research of available literature data.

\section{GEOGRAPHICAL LOCATION}

Sutjeska National Park is located on the far south-eastern part of Bosnia and Herzegovina, on the border with Montenegro. In the region-geographic perspective, it belongs to the eastern part of Central Bosnia, the subregion of Gornje Podrinje. The protected area extends into two administrative-territorial units - the municipalities of Foča and Gacko (Hrelja, 2019).

From a geological point of view, the wider area of the Park was built mainly from the sedimentary and clastic rocks of Mesozoic age, with the presence of the magma rocks (Trubelja, Miladinović, 1969). Triassic sediments have the largest spread within the protected natural area. Cretaceous sediments occupy larger areas in the central and southwestern parts of the Park, while the Jurassic sediments are fragmented in the central and southeastern parts of the area. Sutjeska National Park is located in the 
highest mountain range of Bosnia and Herzegovina, in the northeastern part of the Upper Central Dinarid Geomorphological Region (Lepirica, 2009).

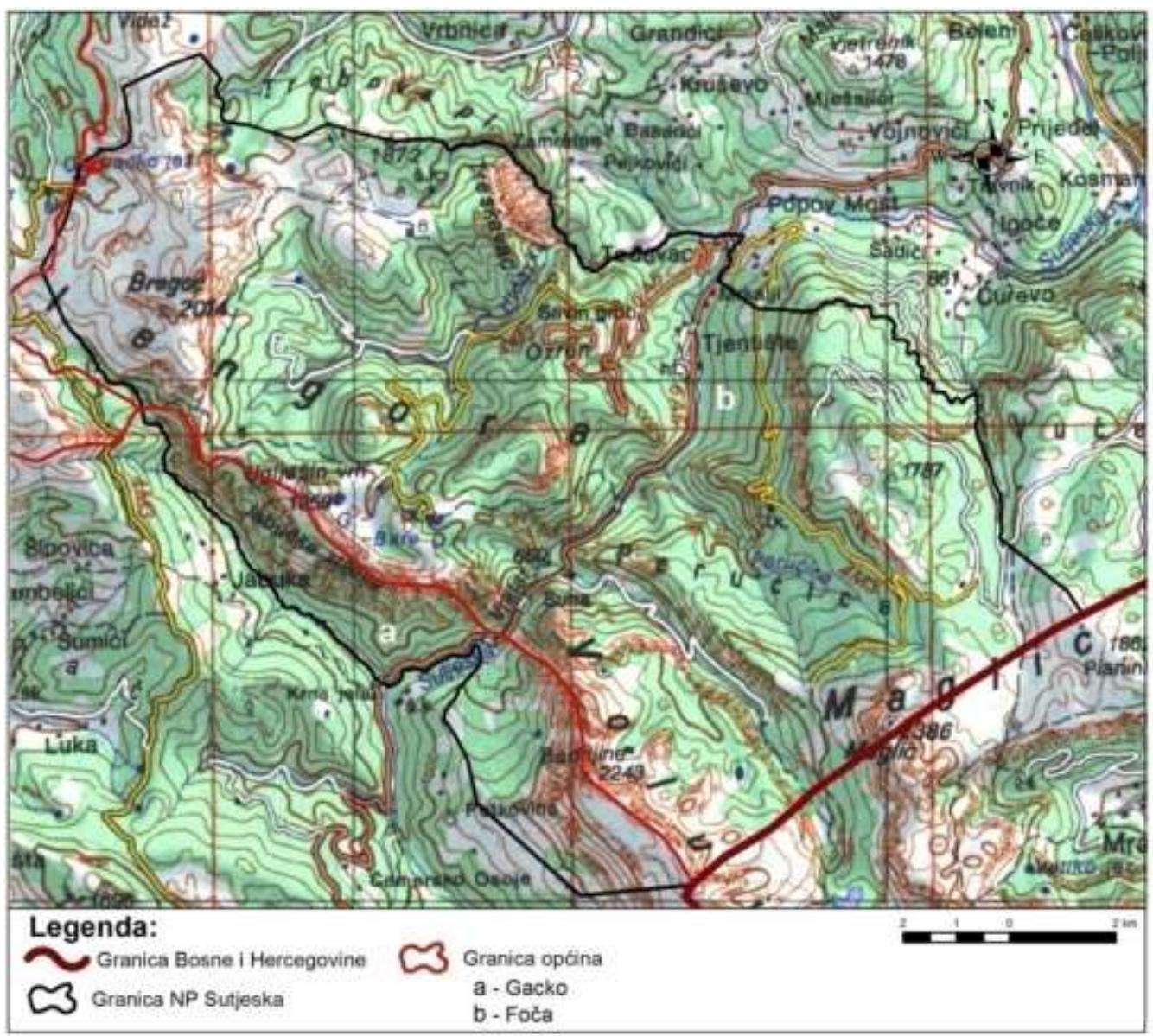

Figure 1. Location of National Park Sutjeska

Author: Hrelja, E., 2017.

From the morphostructural aspect, this high-altitude belt of the Central Dinarides is dominated by a terrain created during Alpine orogenesis (Bušatlija, 1969). This part of the Dinarides is characterized by intense terrain fragmentation, with deep canyons and cliffs over which high mountain peaks emerge. The explored area is under the influence of the Mediterranean and continental climate, with the characteristics of moderate geographic latitudes. According to the Köppen-Geiger classification, the moderately warm and humid climate (C) and the moderately cold climate (D) are represented depending on the influence factors and the thermal characteristics. The lowest temperatures are in January (Čemerno $-4,5^{\circ} \mathrm{C}$, Suha $-3,1^{\circ} \mathrm{C}$ i Tjentište $-1^{\circ} \mathrm{C}$ ), and the highest are in July and August with $13^{\circ} \mathrm{C}$ (Suhoj), $14,9^{\circ} \mathrm{C}$ (Čemerno), and $18^{\circ} \mathrm{C}$ (Tjentište). Annual precipitation at Čemerno is $1.527 \mathrm{~mm}, 1.428 \mathrm{~mm}$ in Suhoj and 1.280 mm in Tjentište (Milosavljević, R., 1969). 
The orographic structures of Lelija and Zelengora build up the watershed between the upper Neretva and the tributaries of Drina. The exploration area is mostly under the drainage of Sutjeska River with its most important tributaries Hrčavka and Perućica, and some terrains are in the karstic hydrographic regime. Sutjeska is the left tributary of the Drina with a surface area of $322 \mathrm{~km}^{2}$ (Hrelja, E., 2019).

Sutjeska National Park is an area of great diversity of flora and fauna. Biogeographic specificity of the area is the result of continental and Mediterranean climate influences. Vertical profile analysis clearly distinguishes the vegetation belts, from pastures, through natural lawns, the transitional woodland/shrub, vegetation shrubs, forests, coniferous forests, mixed forests, areas with scarce vegetation, and areas that are poorly covered by vegetation (bare rocks). One of the largest rainforests in Europe-Perućica (1.434 hectares) is situated in the National Park. (Hrelja., 2019; Hrelja, 2017; Marković, 1970, Plan pravljanja NP Sutjeska, 2013).

\section{ASSUMPTIONS OF TOURIST DEVELOPMENT AND TYPES OF ADVENTURE TOURISM IN SUTJESKA NATIONAL PARK}

In the last few years, adventure tourism has become an increasingly attractive form of tourist demand. Tourists who want to practice this form of tourist movement are looking for destinations that provide a preserved environment or a unique experience of nature. Protected natural areas are especially attractive for this type of tourist movements, where according to numerous researches, the Sutjeska National Park stands out among the most exciting destinations in Bosnia and Herzegovina.

Sutjeska National Park encompasses a distinct mountainous area with numerous biogeographical, hydrographic, geomorphological and climatic specifics. Biogeographically, the central part of the Park is represented by the Nature Reserve Perućica Rainforest, along which stands out the richness of natural grasslands and fairly preserved forest complexes in the rest of the territory. Hydrographically, the area is bordered by the rivers Piva, Drina, the spring of the Neretva, where in addition to watercourses, the richness of natural lakes stands out. In terms of geomorphology, the mountain massifs of Bioča, Vučevo, Maglić, Volujak, Lebršnik and Zelengora stand out. Climatically, the area is suitable as an air spa due to the intertwining of continental and maritime influences and the distinct mountain type of climate.

The peculiarity of the tourist potentials in the Sutjeska National Park, which are the preconditions for the development of adventure tourism, can be singled out through the following:

- The highest mountain peak in the country (Maglić $2386 \mathrm{~m}$ ),

- The largest rainforest in Europe (Perućica),

- The first protected natural area (the Perućica basin in 1954)

- The oldest NP in Bosnia and Herzegovina (Sutjeska in 1962),

- Mountain lakes (Crno, Bijelo, Orlovačko, Donje bare and Gornje bare)

- Canyons and valley extensions (Sutjeska, Hrčavka and Jabučnice),

- Cultural and historical heritage (Sutjeska Memorial Complex)

- Large outdoor pool. 


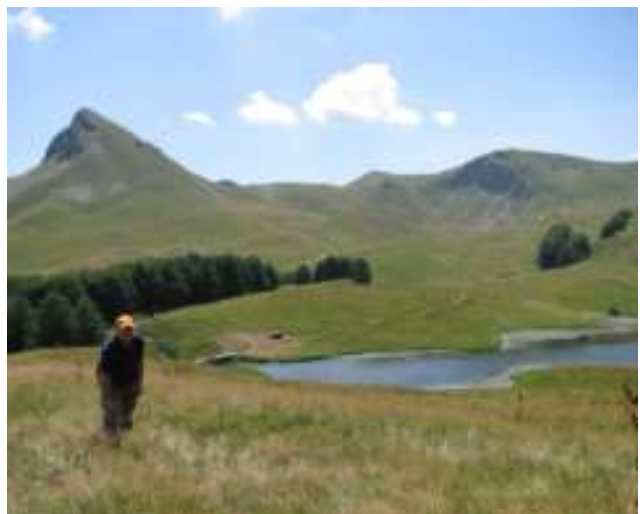

Figure 2. Zelengora

Photo: Hrelja, E.

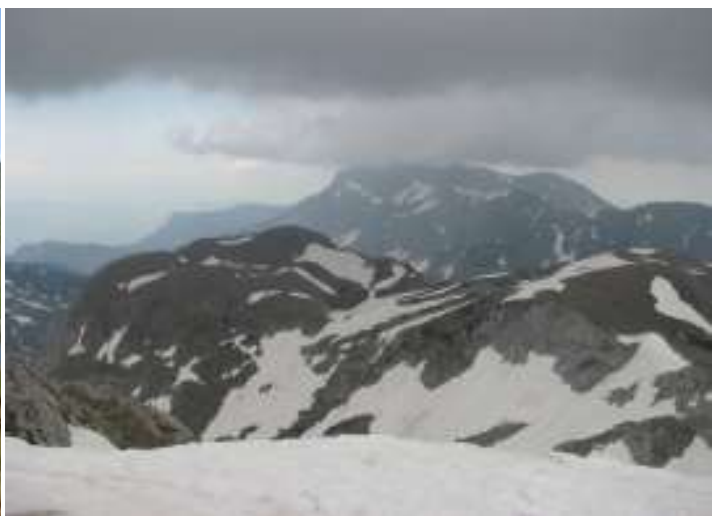

Figure 3: Maglić

Photo: Hrelja, E.

Based on the conducted research with regard to the physical-geographical specifics of the area in Sutjeska National Park, the following types of adventure tourism are being developed:

- Canoeing and kayaking (in the Sutjeska valley in April and May during high water levels);

- Canyoning (in the valley of the river Hrčavka);

- Hiking (hiking trail established on IX route with a total length of $45 \mathrm{~km}$ );

- Jeep and Quad Adventures (jeep race - an event organized by local car clubs);

- Paragliding (Volujak, Maglić and Zelengora);

- Biking (mountain biking in the mountains of NP Sutjeska on the total length of the trail about $25 \mathrm{~km}$ );

- Horse riding on Zelengora (private sector);

- Photo safari (bird watching and large game on Zelengora);

- Climbing (practicing along marked routes);

- Mountain climbing;

- Mountaineering (taking place on the mountain Maglić, although by definition mountaineering is not performed on mountains below $3000 \mathrm{~m}$ above sea level);

- Camping (established camping areas on Orlovačko Lake and Tjentište);

- Passage through the Perućica rainforest (with the obligatory accompaniment of a guide).

In addition to the already mentioned, to complete the tourist offer in Sutjeska National Park, some new forms of adventure tourism are planned, such as survival in the Perućica rainforest, modeled on shows about survival in extreme conditions that are filmed around the world. Some of the planned activities, by definition, do not have the character of exclusively adventure tourism, e.g. film production, but are planned to be developed in order to encourage tourist movements. Also, the possibilities of cross-border connections with the surrounding protected areas (Tara and Durmitor) are highlighted in order to complete the tourist offer and better tourist development. 


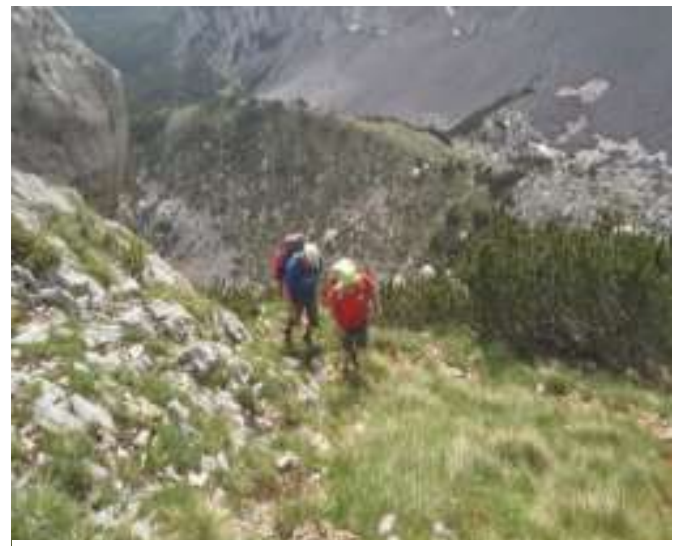

Figure 4: Mountaineering

Photo: Hrelja, E.

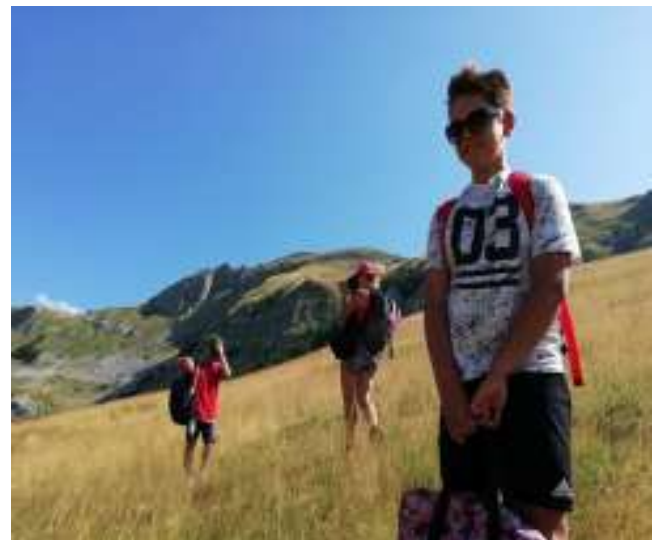

Figure 5: Camping on Orlovačko Lake Photo: Hrelja, E.

\section{CONCLUSION}

The conducted research ultimately confirmed the research assumptions from the introductory part of the paper. Based on the results of the research, it is possible to single out the following concluding assumptions:

- In the Sutjeska National Park, tourist development has decreased significantly, only $0.6 \%$ of tourists compared to 1990 ,

- Attempts are being made to find complementary forms of tourist movements that are in line with nature protection in order to complete the tourist offer of the Park,

- Sutjeska National Park stands out with its precious natural-geographical specifics of the area (the highest mountain peak in the country, the largest rainforest in Europe, the first protected natural area, mountain lakes, canyons and valley extensions, etc.),

- Based on the natural geographical specifics of the Park, forms of adventure tourism are being developed (canoeing and kayaking, canyoning, hiking, Jeep and Quad Adventures, paragliding, biking, climbing, camping, etc.)

Confirming the set assumptions imposes a conclusion on the existence of significant assumptions for the development of adventure tourism in the Sutjeska National Park. In order to complete the tourist offer of this type of tourism, it is necessary to make an inventory of tourist motives, valorization based on the multicriteria evaluation, and mapping of tourist zones (separation of tourist zones for the development of various forms of adventure tourism in accordance with nature protection zones).

\section{LITERATURE}

1. Bušatlija, I., 1969: Geomorfološke karakteristike sliva rijeke Sutjeske, Osnovne prirodne karakteristike, flora i vegetacija Nacionalnog parka Sutjeska, Akademija nauka i umjetnosti Bosne i Hercegovine, posebna izdanja XI, 9-20. 
2. Dražina, A., 2017.: Potencijali razvoja avanturistiĉkog turizma u Zadarskoj županiji, Ekonomski fakultet, Sveučilište u Splitu, Split.

3. Hrelja, E., 2019.: Identification of Negative Factors Affecting Sustainable Development in Sutjeska National Park, Geografski pregled, No. 40., 89-99.

4. Hrelja, E., 2017: Modeli održivog upravljanja zaštićenim prirodnim područjima Bosne i Hercegovine, doktorska disertacija, Prirodoslovno-matematički fakultet, Sveučilište Zagreb.

5. Marković, J., 1970: Geografske oblasti SFRJ, Zavod za udžbenike i nastavna sredstva Srbije, Beograd.

6. Milosavljević, R., 1969: O klimi slivnog područja rijeke Sutjeske, Osnovne prirodne karakteristike, flora i vegetacija Nacionalnog parka Sutjeska, Akademija nauka i umjetnosti Bosne i Hercegovine, posebna izdanja XI, 51-63.

7. Plan upravljanja Nacionalni park Sutjeska, 2013- 2032. godine, Ministarstvo za prostorno uređenje, građevinarstvo i ekologiju Republike Srpske, Banja Luka, 2013.

8. Prostorni plan područja posebne namjene, Nacionalni park Sutjeska 2011-2031. godine, Ministarstvo za prostorno uređenje, građevinarstvo i ekologiju Republike Srpske, Banja Luka, 2013.

9. Trubelja, F., Miladinović, M., 1969: Pregled geološke građe šireg područja Tjentišta i Sutjeske u jugoistočnoj Bosni, Osnovne prirodne karakteristike, flora i vegetacija Nacionalnog parka Sutjeska, Akademija nauka i umjetnosti Bosne i Hercegovine, posebna izdanja XI, 31-38. 